\title{
Lityum-Polimer Piller için Şarj ve Dengeleyici Devre Tasarımı
}

\author{
Ayetül GELEN ${ }^{1 *}$, Emre TÜFEKCIOĞLUº \\ ${ }^{1,2}$ Bursa Teknik Üniversitesi, Elektrik Elektronik Mühendisliği Bölümü, Bursa, Türkiye
}

Geliş / Received: 05/09/2019, Kabul / Accepted: 29/08/2020

\begin{abstract}
Öz
Telefon, tablet, bilgisayar, insansız hava aracı gibi yaşamımızın birçok alanında kullandığımız cihazlarda enerji depolamak ve bu enerjiden faydalanmak için lityum temelli (lityum-iyon, lityum-polimer vb.) piller kullanılmaktadır. Bu pillerin kendi yapılarına, özelliklerine ve ihtiyaçlarına göre şarj edilerek yapılan işlemlerin belli bir standart ve uygunlukta olması gerekmektedir. Bu standartlar sağlandığı zaman pillerden alınan verim ve kullanım süreleri artmaktadır. Bu çalışmada; lityum-polimer (LiPo) pilleri ihtiyaçları doğrultusunda verimli bir şekilde şarj edici ve dengeleyici devre tasarımı sunulmuştur.

Piyasada bulunan ticarileşmiş, belli sertifikalara sahip, LiPo pil şarj cihazları incelenmiş ve eksik özellikleri tespit edilmiştir. $\mathrm{Bu}$ doğrultuda yapılan şarj devresi tasarımından sonra gerekli yazılım ve kontrol sistemi geliştirilmiştir. Geliştirilen yazılım ile kullanıcı dostu bir arayüz ve denemeler sonucu elde edilen verilerin depolanabileceği bir veri havuzu oluşturulmuştur. $\mathrm{Bu}$ veri havuzu sayesinde analiz ve yorumlar yapılabilmektedir. Tasarım aşamasında devre çizim programı, Qt Creator open source arayüz tasarım programı, deney aşamasında ise elektronik donanım tasarımı, mikroişlemci yazılım ortamı, haberleşme protokolü olarak da Zigbee kullanılmıştır. Tasarlanan şarj istasyonu sayesinde pillerden elde edilen verimin artmasını ve kullanılan teknolojik cihazların kullanım sürelerinin uzaması hedeflenmiştir. Ayrıca prototipi yapılan cihazın kablosuz haberleşme alt yapısına sahip olması ile uzaktan erişim özelliği ve mevcut ticari ürünlere göre daha fazla özelliklere sahip olması en önemli yenilik unsurlarıdır.
\end{abstract}

Anahtar Kelimeler: Batarya, pil, LiPo, şarj, arayüz

\section{Charger and Balancer Circuit Design for Lithium-Polymer Batteries}

\begin{abstract}
Lithium-based batteries (lithium-ion, lithium-polymer, etc.) are used to store and utilize energy in devices used in many areas of our lives such as phones, tablets, unmanned aerial vehicles. These batteries should be charged according to their own characteristics and the processes must be of a certain standard and suitability. Thus, the efficiency and duration of use of the batteries increase. In this study, a charger and a balancer design to efficiently charge lithium-polymer (LiPo) batteries are presented.

LiPo chargers, that have certain commercialized certificates, have been examined and their missing features have been determined. The necessary software and control system was developed. A user-friendly interface and a repository where the data obtained as a result of the experiments can be stored have been created. Analysis can be made by this repository. Circuit, interface design programs and also Zigbee for wireless communication for design and experimental studies were used. With the designed charger, it is aimed to increase the efficiency of the batteries and to prolong the service life of devices. Besides, this device has remote access feature by wireless communication and more features than existing commercial products are the most important innovation elements.
\end{abstract}

Keywords: Battery, cell, LiPo, charger, interface 


\section{Giriş}

Güç sistemlerinde tüketiciye sunulan elektrik enerjisinin sürekliliği oldukça önemlidir. Herhangi bir nedenle elektrik kesintisi olduğunda güneş ve rüzgâr gibi kesikli yenilenebilir enerji kaynakları kullanıldığ 1 takdirde medikal, alarm, koruma vb. amaçl1 enerjisiz kalmaması gereken cihazların talebine karşı arz edilecek elektrik enerjisi mevcut olmalıdır. Bunların dışında üreteçler tarafindan fazla üretilen enerji de depolanarak verimlilik ve enerji tasarrufu sağlanabilmektedir. Bu amaçlar için sıklıkla süper kapasitörler, Lityum-İyon, LityumPolimer vb. piller (Li-XX), aküler, nikel bazlı (NiCd, NiMH vb.) piller vb. farklı enerji depolama elemanları kullanılmaktadır (Kozak ve Kozak 2012; Pandzic and Bobanac 2019).

Günlük yaşantımızda düşük güçle çalışan telefon, bilgisayar vb. taşınabilir cihazlar yoğun bir şekilde kullanılmaktadır. Ayrıca elektrikli araçlar, askeri ve özel amaçlı olarak kullanılan insansız hava araçları da şarj edilebilen bataryalar ile enerjilenmektedirler. Her batarya çeşidi kendine has elektrokimyasal özelliklere sahip olup şarj ve deşarj süreçlerinde bu hususlara uyulması gereklidir. Örneğin; kurşun-asit bataryalar, kapasitesinin en az \%20'sine kadar deşarj için uygundur. Ayrıca uzun süreli şarj durumunda (SoC) çalıştırıldığında bataryanın ömrü kısalmaktadır ve hafıza etkisine sahiptirler (Rashid 2017; Khaligh and Li 2010; Bıçak 2018). Bu da tasarımcının şarj edici devre tasarlarken göz önünde bulundurması gereken noktalardır. Aksi takdirde bataryanın çalışma ömrü kısalacaktır. Sonuç olarak her şarj edici cihaz her batarya tipini şarj edememektedir.
$\mathrm{Bu}$ çalışmada özellikle lityum temelli bataryalar üzerine yoğunlaşılmıştır. Çünkü günümüzün popüler konularından olan elektrikli araçlarda lityum temelli piller sıklıkla kullanılmaktadır. Ayrıca; TEİAŞ Haziran/2019 verilerine göre; Türkiye kurulu gücünün \%48,1'ni yenilenebilir enerji kaynakları oluşturmaktadır. Bu oranın \%14'ü ise rüzgâr ve güneş enerjisi temelli güç santralleridir (TEİAŞ 2019). Bu tür sistemlerde de birincil kaynağın azaldı ̆̆ veya yok olduğu durumlarda mümkün mertebe enerji arzının devam etmesi için enerji depolama elamanları kullanılmalıdır. 1679.1-2017 no'lu IEEE Standartlarına göre; lityum temelli bataryaların herhangi bir güç santrali uygulaması için potansiyel araç oldukları da belirtilmiştir (Anonim, 2018).

Lityum temeli bataryalardan LiPo piller diğer türlere göre daha ekonomiktir. Ayrıca uzaktan RF vb. ile kontrol edilen düşük güçlü drone, multikopter vb. insansız hava araçları, oyuncak, ölçüm cihazları ve tıbbi cihazlarda da sıklıkla kullanılmaktadırlar (Lee et al., 2012).

$\mathrm{Bu}$ çalışma ile piyasadaki yabancı menşeli, lityum-polimer (LiPo) piller için olan şarj aletlerine yerli olarak alternatif bir ürün ortaya koymak amaçlanmıştır. Bunun yanında; tasarlanacak ürünün sahip olacağ1 yazılım, arayüz ve haberleşme özelliği ile birçok şarj cihazına karşı farkını ortaya koyabilmesi hedeflenmiştir. Çalışmalar sonucunda milli bir yazılım ve tasarıma sahip, ekonomik olarak rekabet edebilir, 4. sanayi devrimi mantığına uygun, çoklu pil şarj edebilen, dengeleyici özelliği bulunan kullanıcı dostu bir devre tasarımı cihaz elde edilmiştir. Tasarlanan sistemin kablosuz haberleşme ve veri toplama özellikleri; piyasada bulunan eş değerlerine karşı en önemli yenilikleridir. Bu özelliği ile hem 
cihazın hem de şarj edilen pillerin durumu uzaktan izlenebilecek ve müdahale edilebilecektir. Ayrıca; bu tasarımın ülkemizde üretilecek olan birçok ürüne de yol gösterici bir nitelikte olacağ 1 düşünülmektedir. $\mathrm{Bu}$ çalışmanın temel tasarım kısımları (detayları olmaksızın) sadece özet metin olarak uluslararası bir konferansta sunulmuştur (Tüfekcioğlu ve Gelen 2018). $\mathrm{Bu}$ makalede ise arayüz ve sistem tasarımı genişletilmiş ve geliştirilmiş olup prototip üretim aşamaları, devre şemaları, algoritması, uygulama sonuçları ve görselleriyle birlikte açı bir şekilde ortaya konulmuştur.

\section{Materyal ve Metot}

\subsection{LiPo bataryalar}

$\mathrm{Bu}$ bataryalar özellikle nikel temelli olanlara göre çok daha hafif, hemen hemen her boyutta veya şekilde yapılabilen, daha yüksek kapasiteli, enerji yoğunluğu yüksek, yüksek deşarj oranları ve kendiliğinden deşarj olma oranının düşük olması gibi avantajlara sahiptirler. Bunların dışında daha kısa ömürlü, pilin delinme durumu olan, şarj/deşarj için özel dikkat gerektirmeleri olumsuz yönleri olarak sayılabilir (Roger's 2012).

Bir LiPo pilin temel özellikleri; gerilimi ve kapasitesidir. $\mathrm{Bu}$ durum örneğin; Profuse marka LiPo batarya için "3S-2800" gibi k1saca gösterilebilir. Buradaki "3S"; batarya içerisinde seri bağlı üç pil olduğunu göstermektedir. Standart olarak LiPo pillerin anma gerilimleri 3.7 V'tur. $\mathrm{Bu}$ nedenle toplam batarya gerilimi $3.7 \times 3=11.1$ V'tur. $\mathrm{Bu}$ pillerin minimum, denge ve maksimum şarj gerilimleri sırasıyla $3 \mathrm{~V}, 3.7 \mathrm{~V}$ ve 4.2 V'tur. Şarj ve deşarj sıcaklığı ise sırasıyla 0$40{ }^{\circ} \mathrm{C}$ ve $-20-60{ }^{\circ} \mathrm{C}$ 'dir (Andrea, 2012; Kondapalli, 2018). Bu bilgiler ışığında LiPo piller aşırı şarj, derin deşarj ve aşırı sıcaklıklardan korunmalıdır. Ayrıca; Ni temelli pillerin kimyasal özellikleri ve şarj prosedürleri farklı olduğundan dolayı farklı yapıdaki şarj aletlerine sahiptirler. Eğer NiXX pilinin şarj aleti ile LiPo pil şarj edilecek olursa uyumsuzluktan dolayı pil zarar görecektir. En önemlisi de Li temelli pillerin de (LiPo, Li-ion, LiFePo vb.) her birinin şarj durumları farklılık göstermektedir. $\mathrm{Bu}$ sebeple LiPo pillere özgü şarj aleti tasarlanmalı ve kullanılmalıdır.

Dengeleyici devre ile aşırı şarj durumu takip edilmekte ve ayarlanmaktadır. Böylece batarya içindeki tüm pillerin eşit gerilimde şarj olmaları sağlanmaktadır. Bu piller için termal yönetim de en önemli konudur. Çünkü LiXX piller en iyi performanslarını belirli sıcaklık aralıklarında göstermektedir. Pilin verimliliği, güvenliği ve kullanım ömrü çalışma sıcaklığından etkilenmektedir. Hem ortam sıcaklığ hem de pil çalışmasının bir yan ürünü olan 1sı, sistemin genel sıcaklığına katkıda bulunmaktadır (Anonim, 2018).

Sonuç olarak; bütün bu gerekli şartları takip ederek düzenleyen bir Batarya Yönetim Sistemi (BYS) tasarlanmalı ve sisteme entegre edilmelidir. 1679.1-2017 no'lu IEEE standartlarına göre BYS, harici bir şarj cihazına, haberleşme sistemlerine ve istenen herhangi bir uyarı mekanizmasına arabirim oluşturmak için harici kablolara ve bağlantılara sahip olmalıdır. Haberleşme sistemlerinin olması Lityum piller için sistemin çalışmasını, güvenilirliğini ve emniyetini sağlamak için önemlidir (Anonim, 2018).

\section{2. Şarj devreleri}

İlk olarak piyasada bulunan LiPo pilleri şarj eden ticari ürünler incelenerek eksik yönleri belirlenmiş ve bu çalışma kapsamında 
tasarlanan cihazla karşılaştırmalı ürün analizi Tablo 1'de verilmiştir. $\mathrm{Bu}$ çalışma kapsamında; hem ticari olan ürünlere göre daha fazla özelliklere sahip olan, hem LiPo pillerin elektrokimyasal özelliklerine ve ihtiyaçlarına tamamen uygun olan hem de 1679.1-2017 no'lu IEEE standartlarını karşılayan termal yönetimi, kablosuz haberleşme altyapısı ve batarya yönetim sistemi olan şarj ve dengeleyici devre tasarımı gerçekleştirilmiştir. Ek özellik olarak; kullanıcı arayüzü oluşturularak cihaza uzaktan erişim özelliği eklenmiş ve günümüzün popüler konularından olan endüstri 4.0 için de uyumlu bir cihaz prototipi elde edilmiştir. Tasarım aşamasında devre çizim programı, Arduino yazılımdonanım ortam1, Qt Creator open source yazılım ortamı, deney aşamasında ise elektronik donanım tasarımı, haberleşme protokolü olarak da Zigbee kullanılmıştır.

Tablo 1. Karşılaştırmalı ürün analizi.

Tasarlanan şarj aleti

$2 \mathrm{~S}$ ve $3 \mathrm{~S}$ pilleri şarj edebilmektedir

Dengeleyiciye sahip

Şarj sırasında pile aktarılan enerjiyi, akım ve gerilim cinsinden belleğe kayıt özelliği mevcuttur

Termal yönetim hem ortam hem de LiPo pil için mevcuttur

Şarj durumunu gösteren kullanıcı dostu arayüze sahiptir

Kablosuz haberleşme özelliği mevcuttur
A3 Compact Li-Po (2-3S) şarj aleti

$2 \mathrm{~S}$ ve $3 \mathrm{~S}$ pilleri şarj edebilmektedir

Dengeleyiciye sahip

Kayıt özelliği yok

Termal yönetim yok

Arayüzü yok

Her hangi bir haberleşme alt yapısı yok

\section{Tasarım}

Tasarımın amaçlarından birisi de küçük boyutlu ergonomik bir cihaz elde etmektir. $\mathrm{Bu}$ sebeple çoklu görevli entegreler araştırılmıştır ve Texas Instruments'tan bq2954 seçilmiştir. Bu entegre aslında Li-ion veya LiFePo piller için önerilen 5 V'luk VCC ile çalışan 16 bacaklı bir yapıdır (Anonim, 1998). bq2954 entegresinin iç ve dış yapısı Şekil 1'de verilmiştir (Anonim, 1998a). Bu çalışmada, Li-ion piller için bq2954 entegresi içeren bir şarj devresi (Anonim, 1998b) temel alınmış olup LiPo piller için çalışabilecek şekilde devre yapısı düzenlenmiştir. Böylelikle başka bir amaç için üretilen entegre uygun devre düzenlemeleri ile ekstra bir entegre üretilmesine gerek olmaksızın başka Li bazlı bir pil uygulaması için evirilmiştir.

Şekil 2'de modifiye edilmiş hali verilen devrenin tasarım aşamasında yapılan düzenlemeler ve hesaplamalar aşağıdaki gibidir. Hızlı şarj özelliğinin sağlanabilmesi için şarj akımı maksimum 1.2 A olarak seçilerek şarj ana kolundaki direnç üzerindeki gerilim $120 \mathrm{mV}$ ise $\mathrm{I}_{\text {şarj }}=\mathrm{V}_{\text {ölç }} / \mathrm{R} 6$ eşitliğinden;

$1.2 \mathrm{~A}=120 \mathrm{mV} / \mathrm{R} 6 \rightarrow \mathrm{R} 6=0.1 \Omega(5 \mathrm{~W}) \mathrm{d} 1 \mathrm{r}$. 

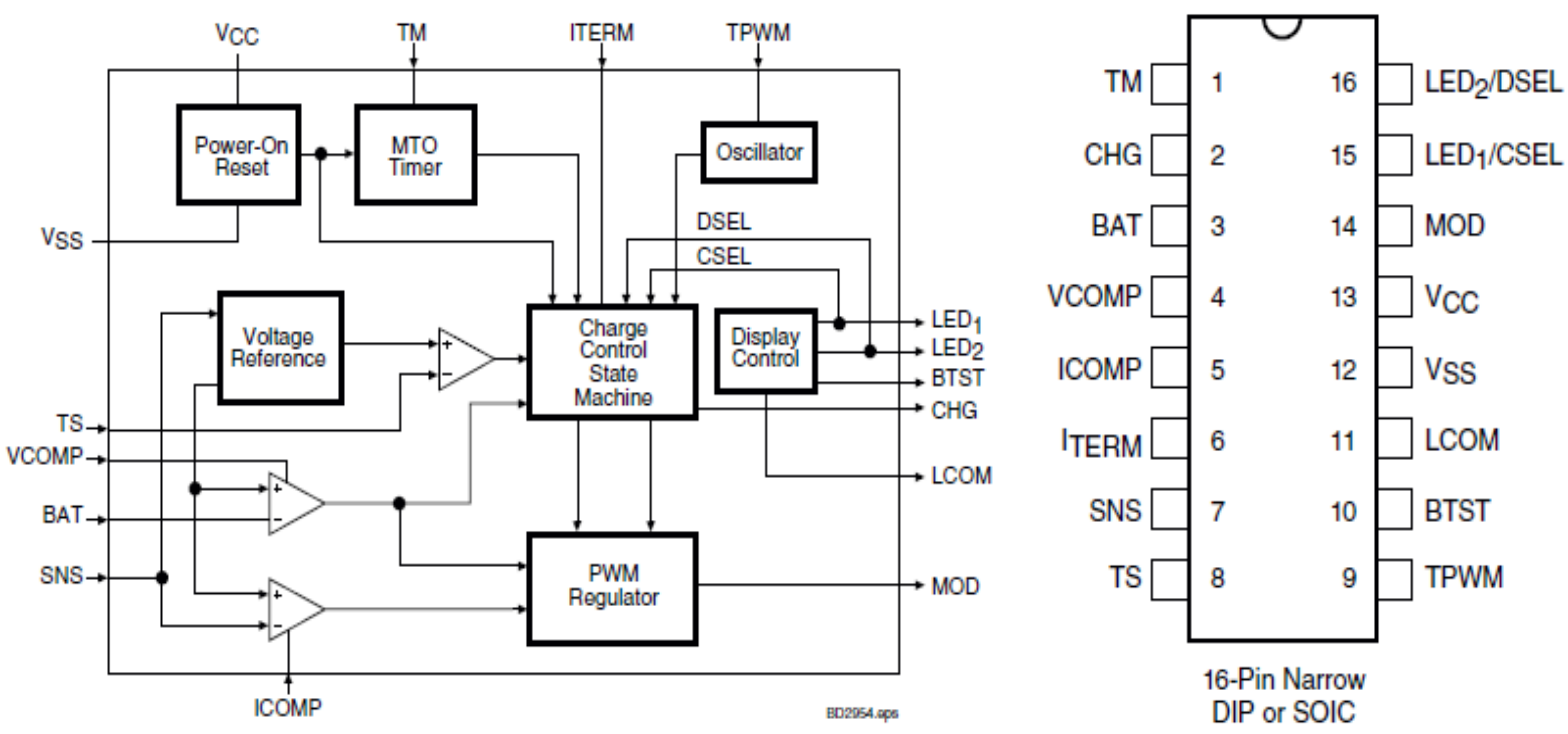

Şekil 1. bq2954 entegresinin iç ve dış yapısı (Anonim, 1998a).

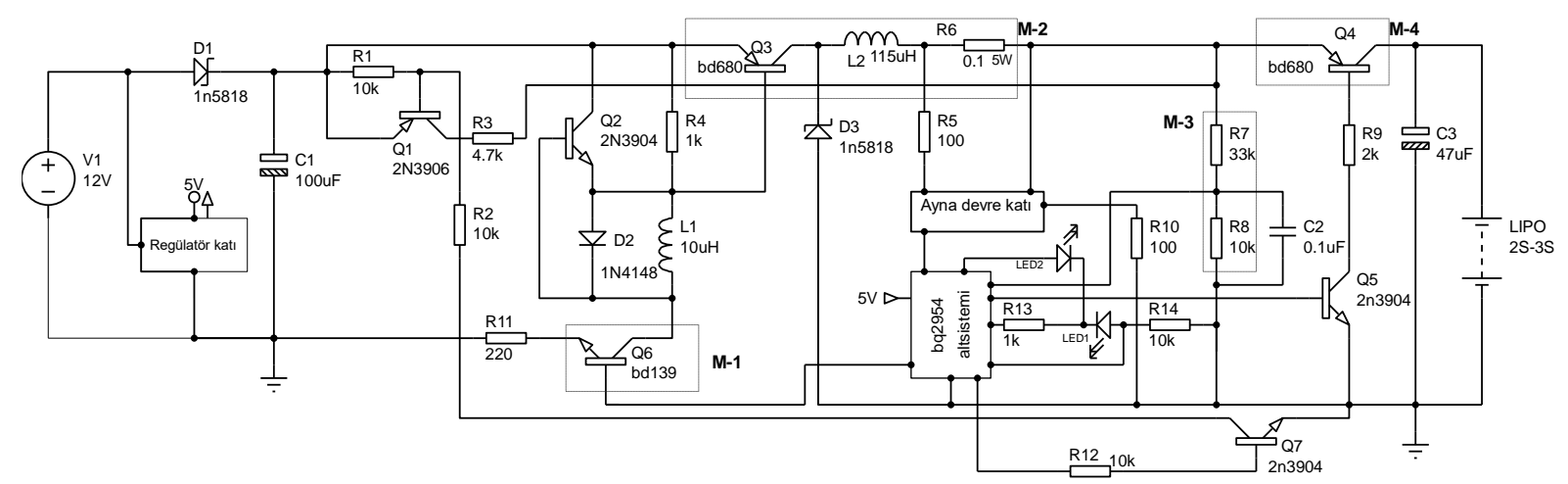

Şekil 2. Li-Po pil şarj devresi.

Devrenin besleme gerilimi nominal adaptör çıkışı olan $12 \mathrm{~V}$ olarak seçilmiş ve devre üzerinde V1 ile gösterilmiştir. Ayrıca bu değer 2S piller için uygun bir gerilimdir (Anonim, 1998b). Vreg=2.05 V olup entegreye bağlı bir değerdir. N pil sayısı, Vpil ise volt olarak pil gerilimidir. 2 adet seri bağlı LiPo pil için hesaplama yapılacak olursa,

$\frac{R 7}{R 8}=\frac{N * \text { Vpil }}{\text { Vreg }}-1=\frac{2 * 3.7}{2.05}-1=2.6$

olarak bir oran elde edilir. Standart direnç değerlerinde bu değere en yakın ve yüksek değer 3.3'tür. Bu durumda; 2S pil için R7 33 $\mathrm{k} \Omega$ seçilirse 3.3'lük oranı sağlamak için $\mathrm{R} 8$ $10 \mathrm{k} \Omega$ olmalıdır.

Örnek alınan devre üzerindeki (Anonim, 1998b) ztx451 npn transistör yerine bd139, ztx789a pnp transistör yerine de bd680 kullanılmıştır. $140 \mu \mathrm{H}$ yerine $115 \mu \mathrm{H}$ (4A) kullanılmıştır. Bu yeni düzenlemeler Şekil 2 üzerinde M-1-2-3-4 olarak kesikli çizgiler ile belirtilmiştir. Buna göre; Şekil 3'te verilen PCB versiyonları elde edilmiştir. $\mathrm{Bu}$ şekildeki üretilen baskı devre kartları ilk versiyon olup şarj edici ve dengeleyici ayrı ayrı basılmıştır. Daha sonra ergonomi, güvenli çalışma vb. nedenlerle iki devre uygun bir şekilde birleştirilerek Şekil 4'teki 
gibi tek kart PCB çizimi yapılmıştır. PCB çizimi yapılan devrenin board üzerindeki hali ve genel sistem Şekil 5'te verilmiştir. Bu kartlar $7.4 \mathrm{~V}, 350 \mathrm{mAh}$ etiket bilgilerine sahip 2S lityum-polimer pili şarj etmek üzere denenmiş ve devrenin olması gerektiği gibi şarj etme özelliğine sahip olması sağlanmıştır.

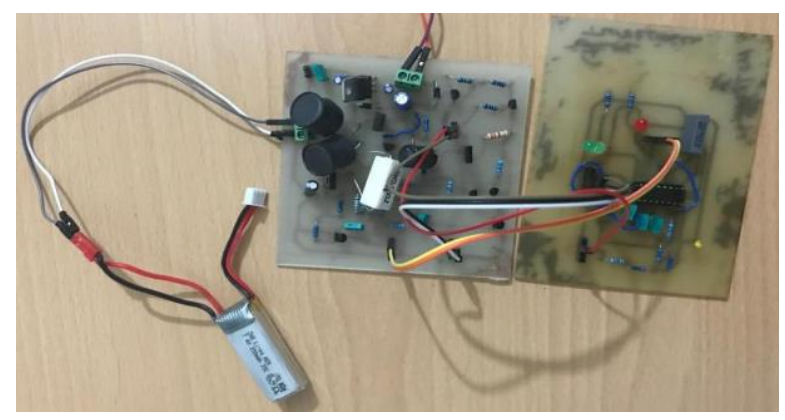

Şekil 3. Şarj edici ve dengeleyici devrelerin baskı devresi.

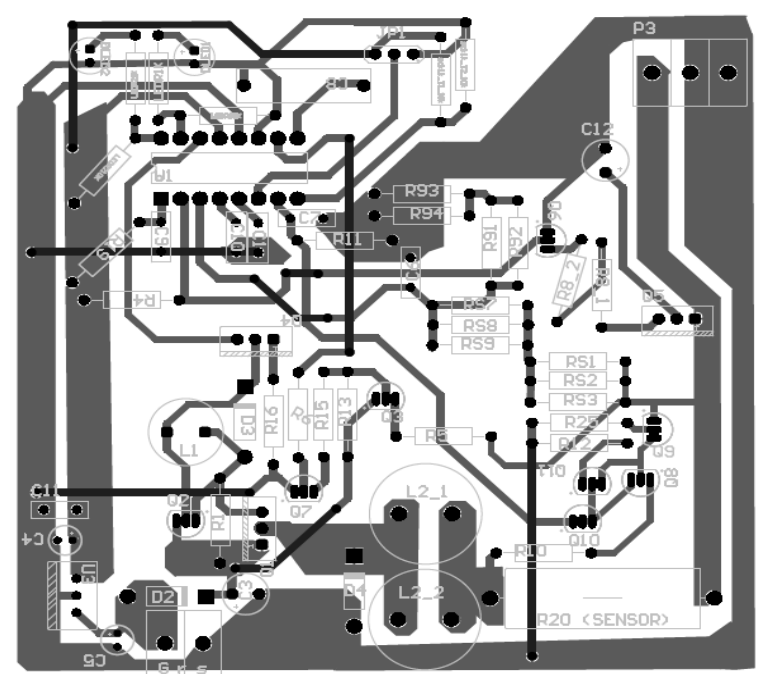

Şekil 4. Devrenin birleştirilmiş PCB çizimi.

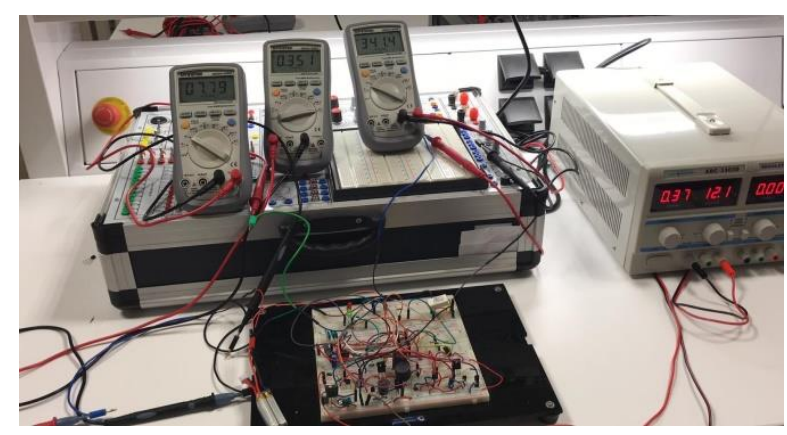

Şekil 5. Çalışma sistemi
$\mathrm{Bu}$ özelliklere sahip olan analog devrenin tasarımından sonraki aşama ise bu tasarımı kontrol edecek yapının, yani denetleyicinin belirlenmesidir. Denetleyici olarak mikroişlemci platformu olan Arduino kullanılmıştır. Arduino 5 V'luk çalışma gerilimine, toplam 16 adet dijital giriş/çıkış pinine ve 6 adet analog giriş pinine sahip bir platformdur (Delebe, 2014; Kanat, 2014). Akım ve gerilim ölçümleri INA219 entegresi yardımıyla yapılmış ve işlemciye bu bilgiler iletilerek geri beslemeli kontrol sistemine de girdi olarak verilmiştir. Son olarak, batarya yönetim sistemi oluşturularak sisteme entegrasyonu yapılmıştır.

Belirlenen kontrol yapısının çalışması için LiPo pillerin ihtiyaçları ve şarj sırasında gerekli olan koşulların sağlanıp sağlanmadığını kontrol eden şarj ve dengeleyici algoritması sırasıyla Şekil 6 ve Şekil 7'de verilmiştir. Bu algoritmaların sistem ile birlikte gerekli koşul ve ihtiyaçları sağlayıp sağlamadığı hususunda kontrollü deneyler yapılarak en uygun algoritma yapısı elde edilmiştir.

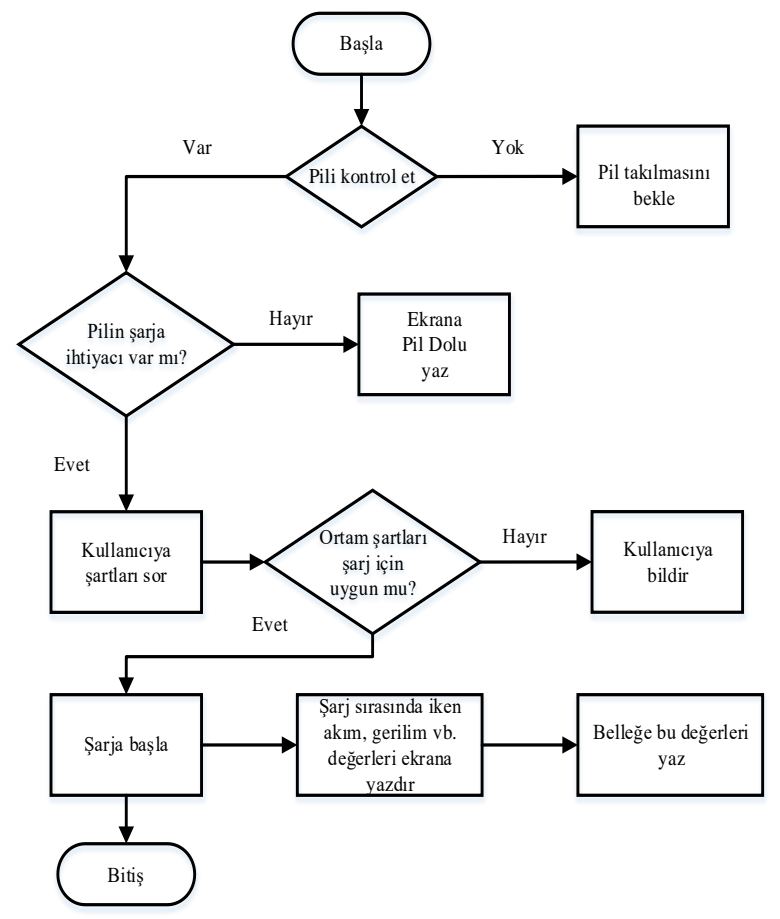

Şekil 6. Pil şarj algoritması. 
Kullanıcı, şarj devresi ve denetleyici arasında iletişimi sağlayan ve kullanıcıya kolaylık sağlamayı hedefleyen arayüz tasarımının gerçekleştirilmesi bir sonraki aşamadır. Şekil 8'de verilen ve Qt Creator open source programı ile hazırlanan arayüzün sistemle uyumlu bir şekilde çalışıp çalışmaması, pilleri düzenli aralıklarla şarj ve deşarj edip bu sürelerin hesaplanması ve denenmesi şeklinde testler yapılmıştır. Kullanıcı arayüzü üzerinde sıcaklık, akım, gerilim, şarj durumu vb. bilgiler mevcuttur. Tasarlanan devrenin uzak bir cihazda (bilgisayar vb.) bir kullanıcı arayüzüne sahip olmasi; sanayide kullanılmasını ve endüstri 4.0 paradigmasına uygun olmasinı da beraberinde getirmektedir.

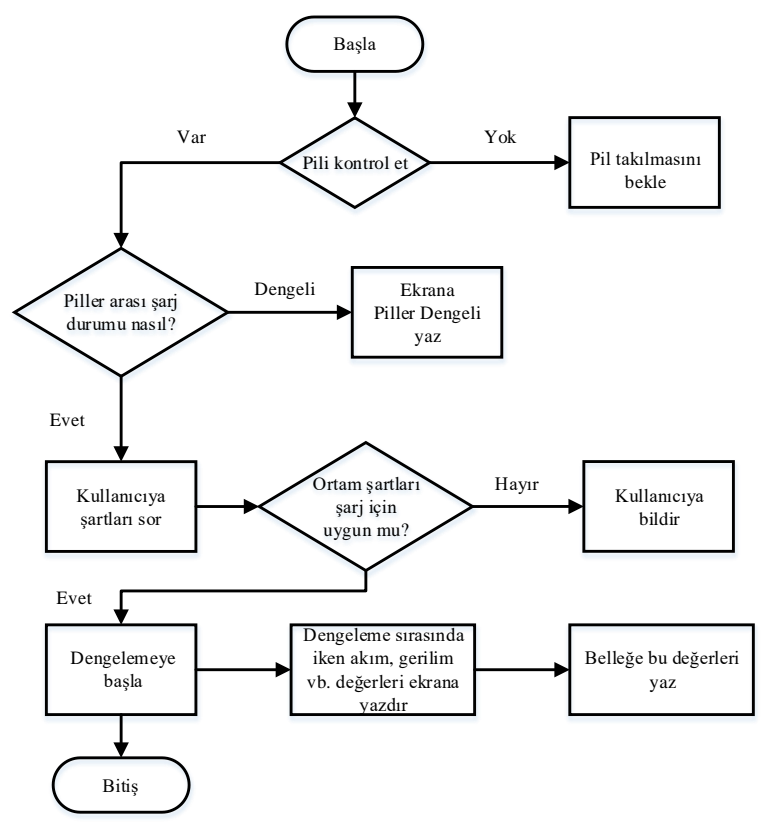

Şekil 7. Dengeleyici şarj algoritması.

Tasarlanan sisteme uzaktan erişim için kablosuz Zigbee haberleşme modülü seçilmiştir. Çünkü bu modüller düşük güç tüketimine sahip olup IEEE 802.15.4 standartlarına sahiptir. Ayrıca termal yönetim için IEEE 1679.1-2017 standartları gereği hem ortam hem de pil sicaklığı uygun sıcaklık sensörleri (DHT11) ile ölçülerek işlemciye iletilmektedir. Belirlenen sıcaklıkların dışına çıkıldığında sistem hem pil için hem de ortam için aşırı sıcaklık uyarısı vererek şarj işlemini kesmektedir. Böylelikle 1sıl güvenlik sağlanmaktadır. Son olarak; tasarlanan sistem fayda/maliyet oran1 açısından en yakın eş değerlerinden daha ekonomiktir.

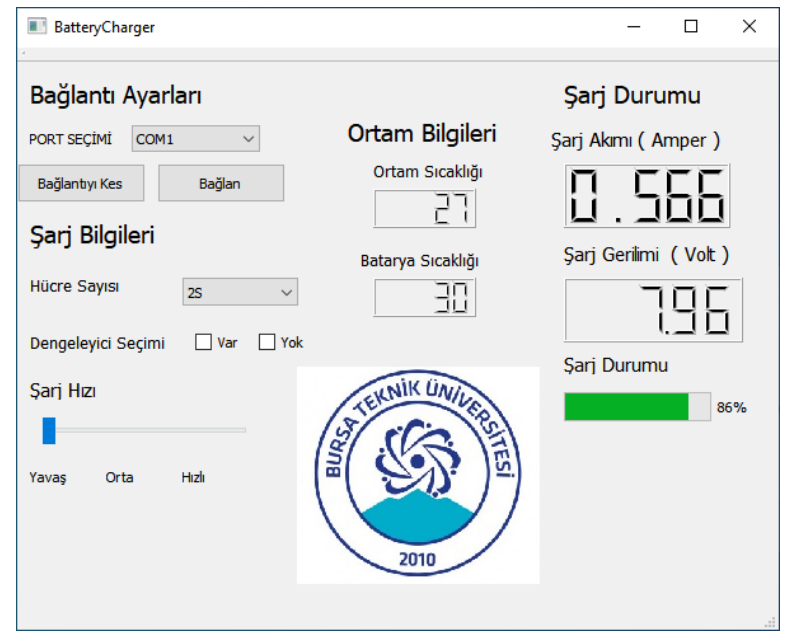

Şekil 8. Kullanıcı arayüzü.

\section{Sonuç}

$\mathrm{Bu}$ projenin sonucu olarak LiPo piller için milli, ekonomik olarak diğer ticari ürünler ile rekabet edebilir, veri toplama, uzaktan haberleşme alt yapısına sahip yeni bir şarj ve dengeleyici devre sayesinde her seviyedeki kullanıcı için faydalı bir ürün olacaktır. Böylelikle 4. sanayi devriminin gerektirdiği gibi minimum insan gücü gerektiren, uzaktan iletişim kurulabilen devre tasarımı; yazılım ve donanım temelli olarak yapılmıştır. Gelecek çalışma olarak LiPo pil dişındaki diğer lityum temelli pillerin de aynı imkânlarla şarj edilmesini sağlayacak üniversal devre tasarımının yapılması planlanmaktadir.

\section{Kaynaklar}

Andrea, D. (2010). "Battery Management Systems for Large Lithium Ion Battery Packs", Artech house, USA, 253. 
Anonim, (1998). "Lithium Ion Charge Management IC with Integrated Switching Controller. Texas Instrument Products", 117.

Anonim, (1998). "Li-Ion Charger Development System. Unitrode", 1-3.

Anonim, (2018). "IEEE Guide for the Characterization and Evaluation of LithiumBased Batteries in Stationary Applications", New York, USA. 1-44.

Bıçak, A. 2018 "Elektrikli araçlarda beş fazlı sabit miknatıslı senkron motorun doğrudan moment kontrolü yönteminin incelenmesi”, Yüksek Lisans Tezi, Bursa Teknik Üniversitesi Fen Bilimleri Enstitüsü, Bursa.

Delebe, E. (2014). "Projeler ile Arduino", Kodlab, İstanbul, 7-16.

Hrvoje, P. and Bobanac, V. 2019. "An Accurate Charging Model of Battery Energy Storage", IEEE Transactions on Power Systems, 34(2), 1416-1426.

Kanat, V. (2014). "Mühendisler için Arduino", Dikeyeksen Yayınevi, İstanbul, 39-50.

Khaligh, A. and Li, Z. 2010. "Battery, Ultracapacitor, Fuel Cell, and Hybrid Energy Storage Systems for Electric, Hybrid Electric, Fuel Cell, and Plug-In Hybrid Electric Vehicles: State of the Art", IEEE Transaction Vehicular Technology, 59(6), 2806-2814.

Kondapalli, B. (2018). "Development and future of drones: Explore heights, Phoenix drone, 23 , https://books.google.com.tr/books?id=FWJ9 DwAAQBAJ\&pg=PA23\&dq $=$ lipo $+4.2+\mathrm{V} \& \mathrm{~h}$ $1=\operatorname{tr} \& s a=X \& v e d=0 a h U K E w j 7 \_v i U v \_j A h X$ NyKYKHfyXD10Q6AEIKzAA\#v=onepage $\& \mathrm{q}=$ lipo $\% 204.2 \% 20 \mathrm{~V} \& \mathrm{f}=$ false.

Kozak, M. ve Kozak, Ş. 2012. "Enerji Depolama Yöntemleri”, Süleyman Demirel Universitesi International Technologic Science, 4(2), 17-29.

Lee, C. Y., Lee, S. J., Lee, Y. M., Tang, M. S., Chen, P. C. and Chang, Y. M. 2012. "In situ Monitoring of Temperature using Flexible Micro Temperature Sensors inside Polymer Lithium-ion Battery", 7th IEEE International Conference on Nano/Micro Engineered and Molecular Systems, Kyoto, Japan, 698.

Rashid, M. H. (2017). "Power Electronics Handbook 4th ed.", Butterworth-Heinemann, England, 1-1522.

Roger's Hobby Center, Inc., "A Guide to Understanding LiPo Batteries", https://rogershobbycenter.com/lipoguide. 20.12.2018.

TEİAȘ, "Kurulu Güç Raporu-Haziran 2019", https://www.teias.gov.tr/sites/default/files/20 19-

07/KURULU\%20G\%C3\%9C\%C3\%87\%20 $\%$ C4\%B0NTERNET\%20HAZ\%C4\%B0RA N\%20AYI_0.pdf, Son erişim tarihi: 01.08.2019

Tüfekcioğlu, E. ve Gelen, A. 2018. "Lityum Polimer Piller için Uzaktan Erişilebilen Şarj Devresi", 2nd Engineers of Future International Student Symposium (EFIS), Zonguldak, Türkiye, 97. 